\title{
SLOVENSKÉ TERÉNNE NÁZVY NA APELATÍVNO-PROPRIÁLNEJ HRANICI*
}

Kl'úč ové slová: slovenské terénne názvy, apelatívum, proprium

\section{VŠEOBECNÝ POHL'AD NA VZŤAH \\ MEDZI APELATÍVNOU A PROPRIÁLNOU LEXIKOU}

Vzt'ahy a hranice medzi apelatívami a propriami sa skúmali z rozličných hl'adísk (filozofických, logických i lingvistických). Výsledky jazykovedných výskumov aj v tejto oblasti závisia vždy od stavu teoretického myslenia danej lingvistickej a onomastickej školy, resp. jednotlivých vedcov. Na úvod naznačíme tento vzt’ah podl'a teórie vlastného mena V. Blanára, ktorá tvorí základ slovenskej onomastickej školy.

Propriá a apelatíva podl'a V. Blanára (1996a: 17) tvoria sémantický protiklad, ktorý má svoje príčiny vo funkčných dimenziách vlastných mien — propriá sa vyznačujú funkciami, ktoré sú vlastné aj apelatívam, a popri tom ešte osobitnými funkciami, ktoré vyplývajú zo špecifiky vlastných mien a súčasne podmieňujú ich špecifiku. Propriá sa vydel'ujú od apelatív práve týmito špecificky onomastickými mimojazykovými funkciami, ktoré na nižšej abstrakčnej úrovni onymického obsahu V. Blanár (1996a: 20) chápe ako generické a diferenčné príznaky, pričom subkategoriálnym príznakom na vyššej asociačnej úrovni, ktorý je charakteristický pre všetky propriá, je všeobecný príznak (funkcia) identifikácia/diferenciácia, resp. spoločensky podmienená identifikácia. Na tejto abstrakčnej rovine sa oblast' proprií stýka aj s apelatívami a súčasne sa už od nich diferencuje, ale na nižších abstrakčných úrovniach onymického obsahu sú významné komponenty vlastných mien, ktoré sú príznačné len pre oblast’ vlastných mien. Z toho vyplýva, že vlastné meno sa so svojím denotátom spája cez jedinečný onymický pojem, ktorý sa pri onymickej nominácii stvárn̆uje v obsahovej stránke vlastného mena.

* Príspevok je jedným z výstupov vedeckej úlohy „Výskum lexiky slovenských terénnych názvov“ (č. 2/0002/14) grantovej agentúry Ministerstva školstva SR a Slovenskej akadémie vied VEGA. 
Apelatívna a propriálna lexika je $\mathrm{v}$ neustálej interakcii, existujú medzi nimi ustavičné prechody, čo súvisí so stále prebiehajúcimi procesmi onymizácie (apelatívum $>$ proprium) a apelativizácie (proprium $>$ apelatívum), otvorenost'ou onymie a spoločenskými potrebami komunikácie (Blanár 2008/2009: 9). Na hranici medzi apelatívnou a propriálnou lexikou stoja určité druhy vlastných mien (napr. etnonymá ${ }^{1}$ alebo sérionymá2), ale aj niektoré členy alebo komponenty proprií, pričom ich propriálny charakter závisí od ich platnosti v spoločenskej praxi a od fungovania v komunikácii ako súčast' vlastného mena (bližšie Valentová 2014c). V. Blanár na základe pozitívneho a negatívneho uplatnenia ukazovatel’ov, akými sú jedinečný akt nominácie (spontánny alebo úradný) ${ }^{3}$, jedinečný pojem a onymický objekt (jedinečnost' individuálna alebo kategoriálna), onymická sémantika (designácia) a nedostatok generického singuláru a plurálu charakterizoval apelatívny alebo propriálny charakter sporných typov lexikálnych prvkov (Blanár 1996a: 50, pozri tabul'ku). Podl'a tejto klasifikácie vyvodil záver, že pomenovania typu pedagogická fakulta obyvatel'ské mená (Žilinčan/Žilinčania) a etnonymá (Poliak/Poliaci) sa vydel'ujú $\mathrm{z}$ rámca vlastných mien napriek tomu, že obyvatel'ské mená a etnonymá sa v slovenskej onomastike chápu ako propriá a tomu je prispôsobený aj ich pravopis (píšu sa s vel'kým začiatočným písmenom).

V. N. Toporov (1962) hovoril o rozličnom stupni vlastnosti „,nomen proprium esse“, čo sa týka prechodných vrstiev medzi apelatívami a vlastnými menami (porov. Blanár 1996a: 133). V. Blanár (1996a: 42) hovoril aj o prechodnej vrstve, t. j. skupine substantív, pri ktorých sa niektoré znaky vlastných mien a niektoré znaky apelatív dost' výrazne nepolarizovali. Podl’a R. Šrámka (1999: 53-54) absolútny protiklad medzi apelatívnou a propriálnou sférou neexistuje. Predpokladá existenciu vel'mi širokého prechodového pásu, v ktorom propria získavajú svoj status nascendi. ${ }^{5}$ Za rozhodujúce znaky ostrosti hranice medzi apelatívami a propriami pokladá špecifiká kategórií „propriálny význam“ a „funkcie proprií“ (Šrámek 2015: 53).

${ }^{1}$ Etnonymá a obyvatel'ské mená sa v rôznych jazykoch vplyvom jednotlivých lingvistických a onomastických škôl chápu alebo nechápu ako vlastné mená a podl’a toho sa aj píšu s vel'kým alebo s malým začiatočným písmenom, napr. slovenská, česká, nemecká, pol’ská, anglická škola ich zarad’uje medzi vlastné mená, v španielskej, švédskej, mad’arskej, bulharskej a bývalej sovietskej škole (ruskej, bieloruskej, ukrajinskej) sa radia k apelatívam (porov. napr. Krško 2015: 83; Semjanová 1980: 250). Podl'a niektorých teórií sú etnonymá vlastné mená v pluráli aj v singulári, podla iných teórií iba v pluráli, v singulári sú apelatíva (pozri List of Key Onomatic Terms). K problematike etnoným sa vyjadrovali aj iní lingvisti a onomastici, napr. D. Berger (1969), E. Coseriu (1989), V. Dalberg (1997), E. Hansack (2004).

${ }^{2}$ R. Šrámek (1999: 14) ich delí na dve skupiny podl’a toho, či pomenúvajú heterogénne (nerovnorodé) alebo homogénne (rovnorodé) hromadné (skupinové) objekty.

${ }^{3}$ Za nevyhnutnú stránku nominácie V. Blanár (1996b: 14) pokladá prijatie a ustálenie mena aspoň užším spoločenským úzom.

${ }^{4}$ Ak však ide o konkrétnu pedagogickú fakultu, aj toto a podobné spojenia sa už pokladajú za vlastné meno, tvoria jeho súčast': Pedagogická fakulta UK v Bratislave (tamže).

${ }^{5}$ Porov. aj Rospond 1970. 
V našom príspevku sa budeme venovat' tým typom slovenských terénnych názvov, o ktorých by sa dalo povedat', že stoja na apelatívno-propriálnej hranici alebo by sa mohli nachádzat' $\mathrm{v}$ takomto prechodovom páse.

\section{VZŤAH TERÉNNYCH NÁZVOV K APELATÍVNEJ LEXIKE}

Názor, že terénne názvy majú v systéme slovnej zásoby miesto najbližšie $\mathrm{k}$ apelatívam, tvoria akýsi prechod od apelatív k propriám, sa všeobecne uznával už oddávna (Majtán 1970: 143). Napríklad podl’a M. Harvalíka (porov. 2004: 42; 2007 : 50) jednotlivé druhy vlastných mien majú $\mathrm{k}$ apelatívam rozlične blízko, ale najbližšie k apelatívam majú práve anojkonymá, pretože pri ich vzniku je prechod od apelatíva k propriu plynulý a pozvol'ný a pri tvorení anojkoným sa bohato využíva apelatívna slovná zásoba a slovotvorné postupy, ktoré sú typické pri tvorení apelatívnej lexiky. Väčšina terénnych názvov vzniká z apelatívnych výrazov a konštrukcií bez osobitných toponymických slovotvorných prostriedkov, bez toponomických formantov (topoformantov), ide o tvorenie tzv. nulovou afixáciou, o prostú proprializáciu (onymizáciu) (Majtán 1994: 16).

M. Majtán (1973: 147) uviedol, že vo väčšine prípadov chotárne názvy vyčleňuje spomedzi apelatívnych výrazov iba špeciálny propriálny príznak sociálnej, spoločenskej identifikácie. ${ }^{6} \mathrm{~V}$ neodsémantizovaných názvoch, ktoré sú totožné s apelatívnymi výrazmi a konštrukciami a s ich vzt’ahom k nazývanému objektu, sa podla M. Majtána (1996: 19) môže prejavovat' dvojako: „1. ak z dvoch alebo viacerých rovnakých objektov iba jeden sa nazýva výrazom, ktorým by sa mohli rovnako dobre nazývat' všetky, a 2. ak z dvoch alebo viacerých možných názvov pre daný objekt sa používa iba jeden. Tak napr. mokré lúky, nachádzajúce sa pri ceste za dedinou a súčasne pri potoku pod horou, sa volajú $Z a$ dedinou, hoci 1 . za dedinou sa nachádza viac objektov, ktoré by sa rovnako dobre mohli takto nazývat', a 2. tieto lúky by sa rovnako dobre mohli nazývat' aj Mokré lúky, Močariny, Pri ceste, Podhorské, Pri potoku a pod." Na tieto úvahy nadväzuje a dopĺña ich M. Harvalík (2007: 51).

\section{TYPY SLOVENSKÝCH TERÉNNYCH NÁZVOV NA} APELATÍVNO-PROPRIÁLNEJ HRANICI

K anojkonymám, ktoré kolíšu na apelatívno-propriálnej hranici, možno zaradit’ priame názvy z II. vzt’ahového modelu (priame pomenovanie objektu — čo je to za objekt $)^{7}$, ktoré sa proprializovali bez formálnych zmien, a to najmä pôvodne apelatívne

\footnotetext{
${ }^{6}$ Porov. aj Blanár 1970: 20.

${ }^{7}$ K charakteristike vzt’ahových modelov pozri Šrámek 1972, 1999: 36-48 a J. Pleskalová 1992: 110.
} 
označenia druhu objektu. Tieto názvy sú základné topografické termíny a topografické pojmy vôbec, napr. Dolina, Drahy, Debra, Črchl'a, Čiert'až (Majtán 1971: 46; 1996: 23). Z hladiska ich fungovania v komunikácii predovšetkým ide o tie, ktoré sa ešte vyskytujú v súčasnej apelatívnej lexike a ich význam je priezračný, napr. Dolina, Lúka, Kopec ap. Napríklad terénnych názvov Kopec je na slovenskom území zatial' štandardizovaných 38 (a dva sídelné objekty). ${ }^{8}$ Po formálnej stránke ide o homonymá (Harvalík 2007: 52). Takéto názvy vzniknú zväčša vtedy, ak sa v okolí nenachádza objekt rovnakého druhu a ako anojkonymá fungujú aj napriek tomu, že v priebehu času došlo k zmene objektu, ktorý pomenúvajú, napr. v Čechách existuje viacero lúk z rybníkov s názvom Rybník, inokedy sa zase pôvodná lúka premenila na pole s názvom Louka (Harvalík 2007: 53). Na Slovensku je napríklad v Sklabini a v Tešedíkove les so štandardizovaným názvom Lúka. Názvy Kopec označujú nielen kopce, vrchy, ale pomenúvajú aj objekty, ako sú polia, lúky, lesy, dokonca močiar. Pri tomto názve však onymickou motiváciou môže byt' aj to, že objekt je viac či menej vyvýšený nad terénom.

Podl’a V. Blánára (1996a: 45, 50) individuálny názov geografického objektu má platnost' vlastného mena, stupeň proprializácie nie je nižší ani v prípadoch typu Pri potoku, Piesok, Piesky, Kratiny, ak má geografický názov podobu apelatívneho výrazu, pretože vznikol spontánnym a jedinečným aktom nominácie (názov sa ustálil v spoločenskom okolí) a dané výrazy sa nespájajú so všeobecným apelatívnym pojmom, ale s jedinečným onymickým pojmom, majú svoju onymickú sémantiku charakteristický je predovšetkým generický príznak [lokalizačný vzt'ah], viazanost' na isté miesto $\mathrm{v}$ teréne.

J. Pleskalová (1978: 296) zaradila medzi anojkonymá, ktoré balansujú medzi apelatívami a propriami, pri názvoch so vzt’ahovým (obsahovým) pomenovacím modelom I. (objekt je pomenovaný podl'a polohy k inému objektu) a II. (priame pomenovanie objektu — čo je to za objekt) predovšetkým tzv. nepriame názvy, ktoré vznikli z predložkových pádov, napr. Za horou, Za starou silnicí, U hranic za vývozem, U horních biskupských hranic. Kladie si otázku, či ide o vlastné meno alebo len apelatívny opis a hoci v nich nie je hranica medzi apelatívami a propriami ostrá, ked'že tieto pomenovania slúžia používatel'om na identifikáciu určitého objektu, plnia tým svoju onymickú funkciu, treba ich pokladat' za vlastné mená (Pleskalová 1978: 197).

Vo všeobecnosti predložkové konštrukcie vo funkcii vlastných mien, tzv. predložkové názvy, ktoré sú z terénnych názvov typické predovšetkým pre chotárne názvy, t. j. názvy hospodársky využívaných objektov (polia, lúky, pasienky, lesy ap.), budili pozornost' už v minulosti najmä z teoretického hl'adiska, a to nielen kvôli problematike apelatívno-propriálneho vzt’ahu, ale aj ich štruktúrnej typológii, klasifikácii, pravopisu (otázka písania vel'kých písmen) a pod. Táto problematika sa znovu stala

\footnotetext{
${ }^{8}$ Podla stavu v databáze štandardizovaných nesídelných geografických názvov Úradu geodézie kartografie a katastra SR k 26. 1. 2012.
} 
aktuálnou nielen v českej onomastike v súvislosti s budovaním koncepcií českých anojkonymických slovníkov, ale aj pri lexikografickom spracovaní slovenských terénnych názvov ${ }^{9}$, ku ktorému znovu pristúpili členky oddelenia dejín slovenčiny, onomastiky a etymológie Jazykovedného ústavu L’udovíta Štúra Slovenskej akadémie vied v Bratislave po ukončení prác na sedemdielnom Historickom slovníku slovenského jazyka (1991-2008) a syntetickom spracovaní prevzatej lexiky z predspisovného obdobia slovenčiny v kolektívnej monografii Staršia slovenská lexika v medzijazykových vzt’ahov (2011).

$\mathrm{V}$ pol'skej onomastike $\mathrm{v}$ minulosti dlhodobo prebiehala diskusia o charaktere a postavení predložkových chotárnych názvov. Napr. K. Dejna (1956) ich chápal ako prechodný, dočasný typ názvov, v ktorom sa substantivizácia ešte neuskutočnila. Substantivizáciu pokladal za hlavný znak prechodu od apelatíva k propriu. Podl'a M. Karaśa (1968) predložkové konštrukcie nie sú ešte názvami, ale iba určeniami smeru alebo polohy daného objektu vo vzt’ahu k iným objektom, ktoré už majú ustálené názvy. S. Hrabec (1950) a J. Bal (1963) ich pokladali za varianty predponových alebo predponovo-príponových názvov a ako samostatnú skupinu terénnych názvov ich vyčlenila T. Gołębiowska $(1964)^{10}$, novšie napr. M. Biolik (1994: 16-17), E. Wolnicz-Pawłowska (2013: 94-107). H. Borek (1984) nazval typ predložkových názvov, v ktorom hlavným nositel’om informácie sa stáva predložka, relačné názvy (pol'. nazwy relacyjne). Charakterizoval ich ako určenia smeru alebo polohy daného objektu vo vzt'ahu $\mathrm{k}$ iným objektom, ktoré už majú ustálené názvy (bližšie p. Borek 1988).

V slovenskej onomastike je už tradíciou, že predložkové pomenovania sa pokladajú za samostatnú, typologicky i obsahovo výrazne odlišnú skupinu terénnych názvov. Nejde pri nich len o obyčajné vyjadrenie momentálneho priestorového vzt’ahu hovoriaceho k objektu, ale o konštantný priestorový vzt’ah vzhl'adom na miesto vzniku názvu, čo znamená, že sa názov používa $\mathrm{v}$ ustálenej podobe bez ohl'adu na momentálnu polohu hovoriaceho k nazývanému objektu, čím sa predložkové názvy výrazne líšia od apelatívnych príslovkových určení miesta (Majtán 1971: 46-47). Predložkové názvy sa nachádzajú takmer na celom území Slovenska pomerne vo vel'kom množstve, tvoria v priemere $21-22 \%$ zo všetkých terénnych názvov, najmenej sú frekventované na Považí od Žiliny po Trenčín (Majtán 1971, 1996: 26). Ich vznik sa vo všeobecnosti vykladá z predložkových konštrukcií okolnostného (príslovkového) určenia miesta (za potokom $>$ Za potokom), elipsou určovaného člena

9 Ku koncepcii lexikografického spracovania slovenských terénnych názov pozri štúdie I. Valentovej (2009b, 2014a, b).

${ }^{10}$ Podrobne charakterizoval diskusiu o tejto problematike, ktorá prebiehala v pol'skej onomastike, ale aj názory napr. ruských onomastikov M. Majtán (1971). K pol'ským autorom, ktorí sa vyjadrovali $\mathrm{k}$ prechodnej zóne medzi apelatívami a propriami a k problematike predložkových názvov, pozri napr. aj práce M. Kucału (1959), S. Sochackej (1970), S. Grodzińského (1973), K. Rymuta (1979), S. Tomaszewskej (1996), J. Dumu (1999: 139-141). 
z príslovkových konštrukcií (lúka za potokom > Za potokom), príp. z vetných konštrukcií, v ktorých zanikol podmet i prísudok (lúka sa nachádza za potokom $>Z a$ potokom), pričom podla M. Majtána (1996: 27) najprijatel’nejší je výklad ich vzniku elipsou určovaného člena. Predložkové konštrukcie rozdelil do dvoch základných typov: 1) predložka - meno a 2) meno - predložka - meno, pričom meno môže byt' substantívum, substantivizované adjektívum, ale aj dvojslovné spojenie adjektívum + substantívum, napr. Za mostom, Pod širokým, Za vyšným mlynom, Vantorkovská pri krízi, Drahy za urbárskym ap. Za charakteristický morfologický príznak predložkových názvov v porovnaní s nominatívnymi názvami možno pokladat možnost' tvorit' iba tri podoby, z ktorých podoba so statickým významom ( $\mathrm{Za}$ potokom, Pri krízi) je základná, ostatné dve s dynamickým významom smerovania k objektu, pomocou ktorého predložkový názov presne lokalizuje nazývaný objekt, alebo od neho (Za potok, Spoza potoka, Ku križu, Od križa), sú len fakultatívne (Majtán 1971: 45-46, porov. napr. aj 1968: 210-211; Miko 1966: 160).

K predložkovým terénnym názvov patria aj také typy názvov I. vzt’ahového modelu, ktoré objekt pomenúvajú vzhl'adom na dva a viac susedných objektov. Napríklad A. Petrov (1929: 95) uviedol v nárečovej podobe v Slovinkách (čast' Nižné Slovinky) názvy pasienkov: Od Velbaskeho bokom turňami aš na Ploščinu, Huttni horb aš ku Krompaskemu horaru, Popod skalu aš do Suhinca ku Porackemu hotaru a názov pol’a Od Višej stupoch aš ku Krompaskemu hotaru. Podobné typy názvov sa získali aj z ostatného územia Slovenska najčastejšie v súpisnej dotazníkovej akcii, napr.: Od ladickej cesty až po maloslažiansky chotár, Od chočianskeho a neverického chotára po neverickú cestu (polia, Sl'ažany), Od hraba/hrabu až do doliny (chotárny názov, ${ }^{11}$ zápis z r. 1647 od Hraba az do doliny, Tekovská Breznica), Od prvého závoza po druhý (lúka, Partizánska L’upča), Od prvej po druhú cestu (pole, hon, Zeleneč; názov zo Základnej mapy ČSSR v mierke 1: 10 000, pôvodne Pri križi), Od štreky po križnu cestu (pole, Cífer), Za múrom po medzu (chotárny názov, Horné Obdokovce), Za vodou po cestu (pasienok, Dolná Štubňa), Nad brehy od môstka po Triblavinu (pole, hon, Chorvátsky Grob, zo Základnej mapy ČSSR v mierke 1 : 10 000), Medzi hradskou a jarkom (Podlužany), Medzi slamou kravina a l'udovým družstvom (pole, hon štátnych majetkov, Šaštínske Stráže), Medzi malým a Gočalových močiarom (pole, Bílkove Humence), Niže cesty $k$ Trnavskej Babe (pole, Špačince) a i.

K terénnym názvom, ktoré nemajú ostrú hranicu medzi apelatívami a propriami, J. Pleskalová (1978: 296) zaradila aj názvy II. vzt’ahového modelu. Mohli by sme k nim pridat' aj zriedkavé viacslovné názvy bez zhody (s nezhodným prívlastkom) s konštrukciou: meno + predložka + meno (Majtán 1996: 26), ktoré však môžu byt'

${ }^{11}$ V niektorých prameňoch sa uvádza, že ide o chotárny názov, ale jeho druh už nie je špecifikovaný. Ak sa pri ich lexikografickom spracovaní nepodarí zistit' druh objektu, v súlade s brnianskou koncepciou Slovníka pomístnich jmen na Moravě a ve Slezsku sa uvádza ako druh objektu „miesto“. $\mathrm{V}$ tomto príspevku $\mathrm{v}$ týchto prípadoch uvádzame, že ide o chotárny názov. 
ešte viac rozvité (napr. aj konštrukcie: meno + predložka + meno + predložka + meno, meno + predložka + meno + meno a i., pričom mená, nezhodné prívlastky, môžu byt' ešte rozvité zhodným prívlastkom), napr. Suroviny až po Hlovek (pasienok, Hlboká), Záhumenice od zelenice po výhon (chotárny názov, Rovensko), Stasová až po koleno na ceste (pasienok, Krivá), Grún pod horou po Behulinu medzu (chotárny názov, Krivá), Diely medzi kanálom a potokom (Dubnica nad Váhom), Ráty medzi úzkou cestou a cestou na Čapáš (polia, Kal'amenová). Pomenúvajú síce objekt priamo, ale bližšie určenie objektu je vyjadrené predložkovou konštrukciou. Podl'a M. Majtána (1996: 23) sú tieto typy názvov II. vzt'ahového modelu pri bežnom, živom používaní vel'mi zriedkavé, príznačné sú pre oficiálne používanie, ked' sa chce presnejšie určit' nazývaný objekt. Síce plnia identifikačnú funkciu, ale nepoužívajú sa v bežnej komunikácii alebo len ojedinele a zväčša slúžia len ako apelatívna deskripcia na lepší opis objektu. Otázne je, či plnia svoje onymické funkcie natol'ko, že ich môžeme označit' statusom vlastného mena. Ponúka sa možnost' za vlastné meno označit' iba prvú čast' pomenovania (substantívum, adjektívum, substantivizované adjektívum): Suroviny, Záhumenice, Stasová, Grúň, Diely, Ráty a určujúci člen alebo členy v postpozícii nezhodný prívlastok alebo prívlastky (d’alej rozvité či nerozvité) pokladat' len za fakultatívnu čast' názvu, resp. fakultatívny funkčný člen alebo členy vlastného mena, ako je to napr. pri živých osobných menách, typy Majdiška zo zadnej izby, Šteuko Baňaneje Kostolňík, Alena Besetka mladá'12 (funkčné členy zo zadnej izby, Kostol'ňik, mladá sa používali fakultatívne).

Ďalšou možnost'ou je nepokladat' ich za fakultatívne funkčné členy vlastného mena, ale klasifikovat' ich čisto len ako apelatívnu deskripciu, ktorá je síce súčast' onymického obsahu vlastného mena (Blanár 1996a: 32), ale platnost' vlastného mena majú iba názvy s designáciou — hierarchickým súborom špecificky onymických (generických a diferenčných) príznakov (funkcií). Prostriedky identifikácie môžu byt' rôzne. Okrem propria môže objekt identifikovat' aj apelatívum, alebo apelatívna deskripcia, numerické a značkové pomenovanie a encyklopedické údaje o objekte (bližšie Majtán 2011: 16). Ak ide len o apelatívnu deskripciu, ktorá má k názvu iba referenčný vzt’ah, nie sú súčast’ou vlastného mena. Takéto typy názvov sa skracujú aj pri štandardizácii nesídelných názvov, pretože podl'a zásad štandardizácie ${ }^{13}$ „z hl’adiska používania názvy nemajú byt’ dlhé. Pri úprave názvu sa dbá, aby sa nevytvárali názvy s viac než tromi plnovýznamovými slovami. Vo výnimočných prípadoch, ak sa názov odvodzuje od existujúceho dvojslovného názvu, možno použit' viac než tri plnovýznamové slová“. Rovnako aj podla zákona o geodézii a kartografii sú okrem iného neprípustné názvy nesídelných geografických objektov, ktoré pozostávajú z viac ako troch plnovýznamových slov ${ }^{14}$.

\footnotetext{
${ }^{12}$ Príklady sú použité z monografií V. Blanára a J. Matejčíka (1978: 61) a I. Valentovej (2009a: 186).

${ }_{13}$ Zásady úpravy a spôsobu písania geografických názvov (2015: 17).

${ }^{14}$ Zákon Národnej rady Slovenskej republiky č. 215/1995 Z. z. o geodézii a kartografii v znení neskorších predpisov.
} 
Podobne na hranici medzi apelatívami a propriami stoja determinované názvy $\mathrm{s}$ vetou, v ktorých je určovacím členom prívlastková vedl'ajšia veta, napr. Stará maša, kde sa ruda léla (Sirk), Železnička, kde Golibu zabilo (Mátraszentimre v Mad’arsku $)^{15}$, z ktorých azda tiež elipsou určovaného člena alebo predmetu vznikli nepriame vetné názvy, pričom zostali iba príslovkové vedlajšie vety miesta, napr. boli sme kosit', kde Ciglana zabilo > Kde Ciglana zabilo (Majtán 1972: 142). Na nepriame vetné názvy je viac dokladov, aj ked' sa vyskytujú iba sporadicky, najviac dokladov je z južnej časti stredného Slovenska, napr. Kde Pal'a st'ali (Cerovo), Kde o Jáne drozd zamrzol, Kde Rózka zamrzla (Pukanec), Kde voda padá (Harmanec), Kde sa Zavod'anove kone povál'ali (Val'kovo) a i. (Majtán 1972: 141; 1996: 26; d’alšie príklady z Pukanca pozri aj Mazúr 1973: 169-170). Vetné názvy sú označované za vlastné mená ako osobitné typy slovenských chotárnych názvov a aj ked' pomenúvajú objekt opisom udalosti, ktorá sa na tomto mieste stala, alebo deja, ktorý je pre pomenovaný objekt príznačný a sú nesklonné, žijú viac desat'ročí napriek tomu, že udalost', podl'a ktorej dostal objekt názov, už nie je podrobnejšie známa (Majtán 1972: 142; 1996: 26). Tieto vetné terénne názvy však neboli štandardizované.

Koncepcia digitálneho Slovníka pomístních jmen na Moravě a ve Sleszku obsahuje triedenie anojkoným podl'a základnej syntaktickej štruktúry názvov, pričom v tejto kategorizácii sa uvádzajú aj typy viacslovných názvov so spojkou $a$ (Čižmárová 2010: 79). Anojkonymá so spojkou $a$, ktoré sa nachádzajú v kartotéke slovenských terénnych názvov Jazykovedného ústavu L. Štúra SAV, sú takmer všetko chotárne názvy, ktoré sa získali zväčša dotazníkovou metódou v súpisnej akcii, alebo sa vyexcerpovali z diplomových prác. Preto je otázne, či skutočne $\mathrm{v}$ takejto podobe $\mathrm{v}$ komunikácii fungovali a či sa vôbec majú chápat’ ako samostatné názvy. Ak ich vyčleníme ako samostatnú skupinu, možno ich rozdelit' do niekol'kých kategórií.

Prvú a najpočetnejšiu skupinu tvorí typ s dvoma rovnocennými názvami, ktoré sú spojené spojkou $a$, napr. Jarček a Morice (Šarišské Dravce), Poloma a Rúbanica (Chocholná-Velčice), Suché a Vel'ké (Tajov). Mohlo íst' o dva názvy jedného objektu alebo o názvy dvoch objektov, ktoré sa nachádzali vedl'a seba. Mohli to byt' objekty rovnakého druhu (Lány a Podskalka — pasienky v Krásnej Hôrke, čo je čast' Tvrdošína, Niže furmanca a Vyše furmanca — polia, hony v Ruskove) alebo rôzneho druhu (Ožnica a Horica - pole a lúka v Dolnom Kubíne, Ostredky a Lúky — pole a lúky v Brezne). Tieto názvy vznikali aj zlúčením rôznych štruktúrnych typov, napr. dvoch priamych názvov (Hôrka a Štepy, Jamy a Bariny, Podčerkiš a Močidla), kombináciou viacslovného názvu so zhodou (so zhodným prívlastkom) a priameho názvu (Bartkov grúň a Dolina, Skalka a Prostredný lán), spojením dvoch viacslovných názvov so zhodou (Dzuranova tôña a Ploštínsky grún, Prostredné hony a Biela hlina), viacslovného názvu bez zhody (s nezhodným

\footnotetext{
15 Príklad z monografie V. Blanára (1950: 54, 111).
} 
prívlastkom) a priameho názvu (Padelky za humnami a Zelnice), priameho názvu a predložkového názvu (Skalka a Pod zámkom), dvoch predložkových názvov ( $Z a$ pol'anou a Na vápenníku) a iných typov (Záhumnia a Biela hlina pri Kaplnke). Príčiny takýchto zápisov môžu byt' dvojaké: a) pri výskume sa do dotazníka chybne zapísali názvy dvoch objektov ako jeden názov, a potom sa v takej podobe vyexcerpovali na kartotečné lístky; b) dva rôzne názvy jedného objektu sa zapísali pomocou spojky $a$ namiesto toho, aby sa oddelili čiarkou. $Z$ toho vznikol dojem, že celé spojenie je jeden názov. V niektorých prípadoch môže íst' o názov honu vtedajšieho jednotného rol'níckeho družstva, ktorý sa utvoril spojením dvoch polí a dostal ich názov. Hony najčastejšie vznikali spájaním viacerých polí a názvy zväčša dostávali podl’a jedného z týchto polí. Ak hon vznikol zlúčením dvoch polí a jeho názov sa potom utvoril z ich názvov pomocou spojky $a$, išlo o umelý názov a je nepravdepodobné, že $\mathrm{v}$ takejto podobe skutočne fungoval v bežnej komunikácii. Skôr možno predpokladat', že sa používal len na administratívne účely podobne ako napríklad dnes rôzne katalógové opisné pomenovania typov výrobkov, ktoré nemožno vcelku hodnotit’ ako vlastné mená (pragmatonymá), pretože obsahujú aj také prostriedky identifikácie, ktoré síce sú súčast'ou onymického obsahu, ale ako sme už spomenuli, nemajú platnost' vlastného mena (porov. Blanár 1996: 32; Majtán 2012: 277-278).

Takýto typ názvov so spojkou $a$ sa nachádza aj pod heslom $A$ v Slovníku pomístních jmen na Moravě a ve Slezsku ${ }^{16}$, napr. Amerika a Trnkovce, Březi a Nádanky, Zadní a U Okrouhlice, Dolní louky a Kykálky a i. Vo výklade sa uvádza: „V soupisech se vyskytují také zápisy ukazující na užití spojky $a$ spíše jen při pouhém výčtu jmen za sebou nebo při popisu objektu, takže jejich propriální charakter je sporný (Cesta ke stavu, Nivám a Podhořám v Loukově KM). O „ústním“ výčtu svědčí zápis nářeční podoby jména Gajdošoj a Juřicoj dílca v Nedašově Lhotě ZL, které se týká dvou samostatných objektů. Společným znakem PJ se spojkou $a$ je těsné sousedství slučovaných (spojovaných) objektů a to, že pro tvorbu PJ jsou objekty chápány jako jeden pojmenovávaný celek. Tento princip byl využit při tvorbě názvů tratí scelovaných za pozemkové reformy v roce 1920 a hojně pak od 50. let 20. stol. při hospodářsko-technické úpravě katastrů $\mathrm{v}$ rámci kolektivizace zemědělství. Proto jsou četná PJ se spojkou $a$ umělého, administrativního původu a vyskytují se povětšině jen $\mathrm{v}$ různých mapových dílech. $\mathrm{V}$ živém úzu se $-\mathrm{s}$ výjimkou výčtu jmen nebo citace z mapy — užívá zpravidla jen jednoho z nich“"17.

Ked’že spojka $a$ sa použila len v spojení názvov dvoch, prípadne viacerých objektov a takéto syntaktické spojenie názvov nemá propriálny charakter, v lexikografickom spracovaní slovenských terénnych názvov sa tieto spojenia na rozdiel od Slovníka pomístních jmen na Moravě a ve Slezsku nekoncipujú ako jeden názov so spojkou $a$, ale rozdel'ujú sa na dva samostatné názvy.

${ }^{16}$ R. Šrámek, heslo A, http://spjms.ujc.cas.cz/entry/56 (cit. 16. 10. 2015).

17 Porov. aj Šrámek 1995: 235. 
Pri väčšine názvov so spojkou $a$ je podobné rozdelenie jednoduché, daktoré názvy môžu byt' problematickejšie. V moravsko-sliezskom materiáli sa nachádza jeden druh názvov so spojkou $a$, ktorý nemožno rozdelit’: „Pojmenování typu Cyril a Metoděj (socha v Radslavicích PR), Svatý Jan a Pavel (kaple v Brušperku FM) zachycují obě postavy vždy společně (jako „celek“) a týkají se vždy jen jednoho objektu — sochy, kapličky apod. (Jsou doložena i předložková PJ tohoto typu: $O$ Jána a Pavla - $\mathrm{s}$ nář. změnou $u>o \mathrm{v}$ předložce -, pole $\mathrm{v}$ Pivíně $\mathrm{PV}$; $U$ Jana a Pavla, m. č. v Brušperku FM; U Petra a Pavla, místo v Budíškovicích JH, pole v Kostelci na Hané PV)"18.

V slovenskom toponymickom materiáli sa nenachádzajú. Dôvodom môže byt' aj to, že názvy sôch sa zarad’ujú medzi ideonymá a názvy kaplniek medzi eklézionymá, patrocíniá. Ked’že tieto názvy nepatria do anojkonymického priestoru, nezist'ovali sa a nezarad'ovali sa do kartotéky terénnych názvov. Podobné názvy sa môžu vyskytovat' napríklad v názvoch baní, šácht a štôlní, ale namiesto spojky $a$ sa štandardizovali so spojovníkom (Adam-Eva, Slovinky).

Ďalším typom je pomenovanie dvoch, ojedinele troch objektov alebo častí jedného objektu, v ktorom spojka $a$ spája zhodné prívlastky. Tieto atribúty môžu charakterizovat' objekty alebo ich časti podl'a polohy: Dolný a Horný trávnik (pole, Dolná Štubňa - čast' Turčianskych Teplíc), Predné, Prostredné a Zadné lány (pole, Záturčie - čast’ Martina), Horné a Dolné záhumnie (polia, Predmier), Predná a Zadná Roveň (pole, Rochovce), Nižné a Vyšné košariská (lesy, doliny, Ruskov); podl'a vel'kosti: Vel'ká a Malá stráža (pasienok, Socovce), Malý a Vel'ký Diel (pole, Sučany), Malý a Vel'ký Buchlov (les, Oslany); podl'a poradia: Prvé a Druhé vráta (skaly, Beluša, Belušské Slatiny), Prvá a Druhá novina (pasienok, Kolbovce); podl'a veku: Starý a Nový Medokýš (pole, Jahodníky — čast' Martina) a podl'a vlastnosti: Horné a Krátke lúky (pasienok, Tlmače). Spojka $a$, ktorá spája viacnásobný prívlastok, sa môže nachádzat’ aj v iných štruktúrnych typoch terénnych názvov, napr. Horná a Dolná Mišovie dolinka (vrch, Vrútky), Na horné a dolné soličné (pole, Valča), Vyšná a Nižná rozhl’adňa prv Meselatov (hon, Ruskov). Rovnaké typy uvádza aj Slovník pomístnich jmen na Moravě a ve Slezsku: Horni a Spodni konec, Přední a Zadní horka, Malé a Velké koňské, Staré a Nové díly, Úzké a Široké čtvrtě (tamže). Aj tieto typy názvov je možné rozdelit', napr. Dolný a Horný trávnik > Dolný trávnik, Horný trávnik, a potom sa už nekoncipujú pod heslom - spojkou $A$.

Posledným typom názvov so spojkou $a$ sú názvy pomenovacieho, vztahového (obsahového) modelu D, ktorý vyjadruje posesivitu, napr. Pankeje a Kubeje záhrady (záhrady, Dolná Ves). Objekt mohli pomenovat' zväčša podl'a súčasného alebo predchádzajúceho majitel'a. Uvedené záhrady vlastnia dvaja majitelia. Aj tu je možné názov rozdelit' a upravit' do spisovnej podoby: Pankovie záhrady, Kubovie záhrady.

${ }^{18}$ R. Šrámek, heslo A, http://spjms.ujc.cas.cz/entry/56 (cit. 16. 10. 2015). 
K pomenovaniam, ktoré balansujú medzi apelatívami, apelatívnou deskripciou a propriami a obsahujú spojku $a$, sa radia aj typy predložkových názvov (aj predložkové konštrukcie ako nezhodné prívlastky) charakterizujúce objekt pomocou d'alších dvoch susedných objektov, medzi ktorými sa nachádza, napr. Medzi malým a Gočalových močiarom (Bílkove Humence), Medzi hradskou a jarkom (Podlužany), Medzi hat'ami a vodami (Gemerské Teplice), Medzi Rudavou a kanálom (Hlboké), Diely medzi kanálom a potokom (Dubnica nad Váhom). Predložka medzi v týchto prípadoch vyjadruje priestorovo polohu objektu vzhl'adom na iné objekty, ktoré ho obklopujú alebo sú umiestnené z obidvoch susedných strán, a preto nemožno nijako spojku $a$ z týchto názvov odstránit'. Ak predpokladáme, že sú to vlastné mená, ktoré fungujú v komunikácii a spĺn̆ajú základné onymické funkcie podobne ako vetné typy názvov, jediné z vyexcerpovaných pomenovaní so spojkou $a$ by sme ich odporučili zaradit' $\mathrm{v}$ tejto podobe do slovníkového spracovania slovenských terénnych názvov a uviest' v zozname názvov aj pod heslom — spojkou $A$ (pozri prílohu). Napriek tomu stále nemožno jednoznačne začlenit' ani tento typ pomenovaní anojkonymických objektov medzi propriá a s určitost'ou potvrdit', že boli prijaté a ustálené užším spoločenským úzom a skutočne fungovali v komunikácii a plnili špecifické onymické funkcie, príp. tento stav pri niektorých je platný aj v súčasnosti. Rovnako by mohlo íst' len o opis objektu pomocou apelatív a/alebo názvov okolitých objektov, ktorým sa informátori snažili pri terénnom výskume čo najvernejšie identifikovat’ objekt.

\section{ZÁVER}

Všetky uvedené typy pomenovaní nesídelných objektov možno chápat' ako vlastné mená, terénne názvy (anojkonymá), ak fungujú v komunikácii a spĺn̆ajú základné onymické funkcie. Nedá sa však vždy a pri každom jednom uvedenom type názvov, resp. pri každom názve presne overit' a s určitost'ou potvrdit', že bol prijatý a ustálený užším spoločenským úzom a skutočne fungoval v komunikácii a plnil špecifické onymické funkcie, príp. či jeho stav je v súčasnosti ešte stále platný, ked’že práve anojkonymické objekty podliehajú často zmenám vzhl'adom na spoločensko-ekonomickú situáciu. Rovnako by preto predovšetkým pri niektorých typoch terénnych názvov, ako sú proprializované druhy objektov, vetné názvy, rozvité predložkové názvy a názvy so spojkou $a$, mohlo íst' len o opis objektu pomocou apelatív a/alebo názvov okolitých objektov, ktorým sa informátori snažili pri terénnom výskume čo najvernejšie identifikovat' objekt explorátorovi. Ked’že status uvedených pomenovaní nie je napriek všetkému úplne jasný, zaradili by sme ich do prechodnej skupiny medzi propriami, ktoré majú onymický obsah (designáciu), a apelatívnym alebo apelatívno-propriálnym opisom (charakteristikou, deskripciou), ktorý je tiež prostriedkom identifikácie objektu, poskytujúcim informácie o objekte, ale presahuje rámec vlastných mien. Takýto apelatívny alebo apelatívno-propriálny opis môže tvorit' len referenčný vzt’ah medzi vlast- 
ným menom a objektom, byt' súčast'ou onymickej sémantiky, ale nemusí byt' vlastným menom. Možno o nich uvažovat' aj tak, že sa nachádzajú v prechodovom páse medzi apelatívnou a propriálnou lexikou, $\mathrm{v}$ ktorom propriá získavajú svoj status nascendi, aj ked’ niektoré možno len na určitý čas a vo vel'mi úzkom spoločenskom úze.

\section{LITERATÚRA}

Bal J. 1963: „Niemotywowane“ pluralis niektórych nazw terenowych, „Onomastica“ VIII, s. 171-194.

Berger D. 1969: Sind Völkernamen und andere pluralische Personennamen Appellativa?, [v:] H. H. Hornung (red.), 10. Internationaler Kongreß für Namenforschung (Wien 8.-13. IX. 1969). Abhandlungen. Disputationes ad montium vocabula aliorumque nominum significantes pertinentes, vol I, Verl. der Wiener Medizinischen Akademie, Wien, s. 73-81.

Biolik M. 1994: Mikrotoponimia byłego powiatu ostródzkiego, Wyd. WSP, Olsztyn.

Blanár V. 1950: Príspevok ku štúdiu slovenských osobných a pomiestnych mien v Mad'arsku, Slovenská akadémia vied a umení, Bratislava.

Blanár V. 1970: Špecifikum onomastiky, [v:] Š. Krištof (red.), Zborník materiálov zo sympózia o teoretických a metodologických otázkach onomastiky a 2. slovenskej onomastickej konferencie v Nitre 22.-24. mája 1969, Slovenské pedagogické nakladatel'stvo, Bratislava, s. 15-35.

Blanár V. 1996a: Teória vlastného mena. (Status, organizácia a fungovanie v spoločenskej komunikácii), Veda, Bratislava.

Blanár V. 1996b: Medzi apelatívom a vlastným menom, [v:] M. Majtán, R. Ruščák (red.), 12. slovenská onomastická konferencia a 6. seminár „, Onomastika a škola“. Prě̌ov 25.-26. 10. 1995. Zborník referátov, Fakulta humanitných a prírodných vied Prešovskej univerzity-Jazykovedný ústav L'. Štúra, Prešov, s. 13-21.

Blanár V. 2008/2009: Vlastné meno vo svetle teoretickej onomastiky, Slovenská jazykovedná spoločnost' SAV-Jazykovedný ústav L. Štúra SAV-Vydavatel'stvo Matice slovenskej, Bratislava-Martin.

Blanár V., Matejčík J. 1978: Živé mená na strednom Slovensku. 1. 1. Designácia osobného mena. Slovenské pedagogické nakladatel'stvo, Bratislava.

Borek H. 1984: Z problematyki nazwotwórstwa toponimicznego, „Zeszyty Naukowe WSP w Opolu. Językoznawstwo“ IX, s. 57-63.

Borek H. 1988: Nazwy relacyjne w toponimii, [v:] K. Zierhoffer (red.): V Ogólnopolska Konferencja Onomastyczna. Księga referatów, Wyd. Naukowe UAM, Poznań, s. 43-51.

Coseriu E. 1989: Der Plural bei den Eigennamen, [v:] F. Debus, W. Seibicke (Hrsg.), Reader zur Namenkunde I. Namentheorie, Georg Olms Verl., Hildesheim-Zürich-New York, s. 225-240.

Čižmárová L. 2010: Tvorba elektronického slovniku pomístnich jmen na Moravě a ve Slezsku, „Acta onomastica“ 51, s. 79-93.

Dalberg V. 1997: Zum fragwürdigen proprialen Status der Ethnonyme, [v:] K. Hengst, D. Krüger, H. Walther, I. Bily (Hrsg.), Wort und Name im deutsch-slavischen Sprachkontakt. Ernst Eichler von seinen Schülern und Freunden, Böhlau, Köln-Weimar-Wien, s. 33-47.

Dejna K. 1956: Terenowe nazwy ślaskie, „Onomastica“ II, s. 103-126.

Duma J. 1999: Nazwy rzek lewobrzeżnego Mazowsza z całym dorzeczem Pilicy, Tow. Naukowe Warszawskie, Warszawa.

Gołębiowska T. 1964: Terenowe nazwy orawskie, Wyd. UJ, Kraków.

Grodziński S. 1973: Zarys teorii imion własnych, PWN, Warszawa.

Hansack E. 2004: Das Wesen des Namens, [v:] A. Brendler, S. Brendler (Hrsg.), Namenarten und ihre Erforschung. Ein Lehrbuch für das Studium der Onomastik, Baar-Verl., Hamburg, s. 51-65.

Harvalík M. 2004: Synchronní a diachronni apekty české onymie, Academia, Praha. 
Harvalík M. 2007: K prechodům mezi apelativni a propriálni sférou jazyka, [v:] M. Považaj, P. Žigo (red.), Súradnice súčasnej onomastiky. Zborník materiálov zo 16. slovenskej onomastickej konferencie, Veda, Bratislava, s. 49-54.

Hrabec S. 1950: Nazwy geograficzne Huculszczyzny, PAU, Kraków.

Karaś M. 1968: Toponimia Wysp Elafickich na Adriatyku, Ossolineum, Wrocław.

Kartotéka a digitálna databáza terénnych názvov Jazykovedného ústavu L. Štúra SAV, Bratislava.

Kopecká M., Laliková T., Ondrejková R., Skladaná J., Valentová I. 2011: Staršia slovenská lexika v medzijazykových vztahoch, Veda, Bratislava.

Krško J. 2015: Soták — apelatívum, či proprium? Alebo o onymickej stránke skupinových názvov, [v:] I. Valentová (red.), 19. slovenská onomastická konferencia. Bratislava 28.-30. apríla 2014. Zbornik referátov venovaný PhDr. Milanovi Majtánovi, DrSc., k osemdesiatym narodeninám, Veda, Bratislava, s. 83-87.

Kucała M. 1959: Co już jest, a co jeszcze nie jest nazwa wlasna, „Onomastica“ V, s. 67-100.

List of Key Onomastic Terms in English, http://www.icosweb.net/index.php/terminology.html (cit. 17. 03. 2016).

Majtán M. (red.) 1991-2008: Historický slovník slovenského jazyka, Veda, Bratislava.

Majtán M. 1968: K výskumu slovenskej mikrotoponymie, „Jazykovedný časopis“ 19, s. 205-215.

Majtán M. 1970: K propriálnosti chotárnych názvov, [v:] Š. Krištof (red.), Zborník materiálov zo sympózia o teoretických a metodologických otázkach onomastiky a 2. slovenskej onomastickej konferencie v Nitre 22.-24. mája 1969, Slovenské pedagogické nakladatel’stvo, Bratislava, s. $143-150$.

Majtán M. 1971: Z problematiky predložkových názvov, „Jazykovedný časopis“ 22, č. 1, s. 41-48.

Majtán M. 1972: Chotárne názvy vetného typu, „Slovenská reč“ 37, s. 140-143.

Majtán M. 1973: Štruktúrne typy slovenských chotárnych názvov, [v:] M. Majtán (red.), 4. slovenská onomastická konferencia. Bratislava 9.-10. 11. 1971. Zbornik referátov, Vydavatel'stvo Slovenskej akadémie vied, Bratislava, s. 147-160.

Majtán M. 1994: Motivácia a lexikálna sémantika, [v:] E. Krošláková (red.), Jazyková a mimojazyková stránka vlastných mien. 11. slovenská onomastická konferencia. Nitra 19.-20. 5. 1994. Zborník referátov, Jazykovedný ústav L. Štúra-Vysoká škola pedagogická, Bratislava-Nitra, s. 15-19.

Majtán M. 1996: Z lexiky slovenskej toponymie, Veda, Bratislava.

Majtán M. 2011: Prostriedky identifikácie, [v:] I. Valentová (red.), Život medzi apelatívami a propriami. Jazykovedné štúdie XXIX, Veda, Bratislava, s. 15-19.

Majtán M. 2012: Pragmatonymá sú vlastné mená, [v:] M. Ološtiak (red.), Jednotlivé a všeobecné v onomastike. 18. slovenská onomastická konferencia, Filozofická fakulta Prešovskej univerzity, Prešov, s. 277-278 (http://www.pulib.sk/elpub2/FF/Olostiak3/index.html; cit. 17. 03. 2016).

Mazúr S. 1973: Ďalši vývin názvov vetného typu, [v:] M. Majtán (red.), 4. slovenská onomastická konferencia. Bratislava 9.-10. 11. 1971. Zbornik referátov, Vydavatel'stvo Slovenskej akadémie vied, Bratislava, s. 169-170.

Miko F. 1966: Skloňovanie názvov typu Pod Hradovou, „Slovenská reč“ 31, s. 157-160.

Petrov A. 1929: Karpatoruské pomístní názvy z pol. 19. a z poč. 20. st., Česká akademie věd a umění, Praha.

Pleskalová J. 1978: K hranici medzi apelativy a proprii (na materiálu pomistních jmen), „Zpravodaj Místopisné komise ČSAV“"19, s. 296-300.

Pleskalová J. 1992: Tvoření pomístních jmen na Moravě a ve Slezsku, H\&H, Jinočany.

Rospond S. 1970: Prawo polaryzacji w onomastyce, [v:] Š. Krištof (red.), Zborník materiálov zo sympózia o teoretických a metodologických otázkach onomastiky a 2. slovenskej onomastickej konferencie $v$ Nitre 22.-24. mája 1969, Slovenské pedagogické nakladatel'stvo, Bratislava, s. 37-43.

Rymut K. 1979: Granica czy strefa przejściowa między nomen appellativum a nomen proprium, „Slavica Lundensia“" 7 , s. 175-180. 
Semjanová M. 1980: O mieste etnonyma a obyvatel'ského mena na rovine apelatívum-proprium, [v:] M. Majtán (red.), Spoločenské fungovanie vlastných mien. 7. slovenská onomastická konferencia. Zemplinska Širava 20.-24. 9. 1976. Zborník materiálov, Veda, Bratislava, s. 249-253.

Sochacka S. 1970: Wyrażenia przyimkowe jako struktura nazewnicza, „Zeszyty Naukowe WSP w Opolu. Językoznawstwo“" 4, s. 77-128.

Šrámek R. 1972: Toponymické modely a toponymický systém, „Slovo a slovesnost“ 33, s. 304-318.

Šrámek R. 1995: Ukázka lexikografického zpracováni pomistních jmen z Moravy a Slezska, „Acta onomastica“" 36 , s. 235-511.

Šrámek R. 1999: Úvod do obecné onomastiky, Masarykova univerzita, Brno.

Šrámek R. 2014: A, [v:] Slovnik pomistních jmen na Moravě a ve Slezsku, http://spjms.ujc.cas.cz, Brno: dialektologické oddělení Ústavu pro jazyk český AV ČR, v. v. i. C 2014-(cit. 16. 10. 2015).

Šrámek R. 2015: Propriální sféra jazyka a hranice vlastních jmen, [v:] I. Valentová (red.), 19. slovenská onomastická konferencia. Bratislava 28.-30. apríla 2014. Zborník referátov venovaný PhDr. Milanovi Majtánovi, DrSc., $k$ osemdesiatym narodeninám, Veda, Bratislava, s. 46-54.

Tomaszewska S. 1996: Polskie mikrotoponimy motywowane wyrażeniami przyimkowymi, Wyd. UŁ, Łodź.

Toporov V. N. 1962: Iz oblasti teoretičeskoj toponomastiki, „Voprosy jazykoznanija“ 11, zoš. 6, s. 8-16. Valentová I. 2009a: Živé osobné mená v hornonitrianskej oblasti, Veda, Bratislava.

Valentová I. 2009b: Ku koncepcii pripravovaného Slovníka slovenských anojkoným, „Slovenská reč“ 74 , s. 283-291.

Valentová I. 2014a: Zo zásad koncepcie spracovania lexiky slovenských terénnych názvov, [v:] A. Gałkowski, R. Gliwa (red.), Mikrotoponimia i makrotoponimia. Problematyka wstęna, Wydawnictwo UŁ, Łódź, s. 155-165.

Valentová I. 2014b: Výstavba heslových slov slovnika lexiky slovenských terénnych názvov, [v:] S. Ondrejovič, L. Satinská, J. Vrábl'ová (red.), Štefan Peciar a moderná lexikografia, Veda, Bratislava, s. 280-296.

Valentová I. 2014c: Apelatívny člen, apelativny komponent propria a informácia o propriu v podobe apelativa, [v:] E. Minářová, D. Sochorová, J. Zítková (red.), Vlastní jména v textech a kontextech, Masarykova univerzita, Brno, s. 40-46.

Wolnicz-Pawłowska E. 2012: O nazwach wodnych w Polsce, DiG, Warszawa.

Zásady úpravy a spôsobu písania geografických názvov. Príloha č. 1 k Smernici na štandardizáciu geografických názvov č. 84.11.13.31.71.00-15, 2015, Úrad geodézie, kartografie a katastra Slovenskej republiky, Bratislava, http://www.skgeodesy.sk/sk/ugkk/geodezia-kartografia/standardizacia-geografickeho-nazvoslovia/dokumenty-k-cinnosti/ (cit. 22. 06. 2016).

\section{THE SLOVAK ANOIKONYMS ON THE APPELLATIVE-PROPRIAL BORDER}

\section{SUMMARY}

There are certain types of expressions and some of their elements and components that are in a transition sphere between the appellative and proprial lexicon. Their proprial or appellative character depends on their use in society and on their functioning in communication. Ethnonyms are traditionally considered a typical example of such expressions. Nevertheless, it is also anoikonyms that stand close to appellatives in the vocabulary system, because in the process of their forming the transition from appellatives to proper names is fluent and their formation is based on the appellative vocabulary and word-formation processes typical of appellative word-formation. The paper deals with some types of Slovak anoikonyms that can be described as standing on the appellative-proprial border.

K ey w ord s: Slovak anoikonyms, appellative, proper name 